\title{
JURNALISTIK DAKWAH (SEBUAH MODEL KOMUNIKASI ISLAMI)
}

\author{
Oleh : Suf Kasman* \\ Dosen Jurusan Jurnalistik Fakultas Dakwah dan Komunikasi UIN \\ Alauddin Makassar
}

Email : sufkasman@gmail.com

\begin{abstract}
One of the functions of journalism is as defenders of truth and fairness. Many people refer to it as a universal function and ideal. A journalist is never asked to provide information, but it is its own initiative. They offer an event that, in the presence of a reporter (messenger), will bridge the relationship between man, nature, and not the relationship between conqueror or conquered, or God's servant, but the relationship of togetherness in submission to Allah. Its existence is equivalent to the ministry, bureau, or other parts, which both have their own methods for achieving the goals of da'wah.

The development dissemination of Islam tends to increase through electronic media, as well as print media. Journalism as a tool has a very powerful effect though it may appear slower, but leaves a deep impression.

The existence of journalistic da'wah not only as a information tools of education and entertainment, but its main purpose is a religious leader as mission developing "Amar Ma'ruf Nahi Munkar”, in Al-Qur'an S. Ali Imran (3): 104.
\end{abstract}

\section{Keywords :}

Jornalistic, Da'wah, Communication and Islamic

\section{Pendahuluan}

Kajian tentang Jurnalistik Dakwah, memang diakui relatif masih baru atau sebut saja masih balita. Hal ini disebabkan karena disiplin ilmu jurnalistik dakwah juga relatif masih sangat baru. Jurnalistik dan Dakwah merupakan dua kajian yang akan dikompromikan dalam tulisan ini. Setidaknya ada dua hal yang harus diklarifikasi sebelum masuk pada pembahasan. Pertama, kata Jurnalitik dalam terminologi "jurnalistik dakwah" berfungsi sebagai kata sifat sehingga bisa dipahami bahwa kegiatan dakwah yang dimaksud adalah bersifat atau melalui media jurnalistik. Kedua, oleh karena jurnalistik bagian dari komunikasi maka metode penelitian "jurnalistik dakwah" dalam tulisan ini akan meminjam metode (model) penelitian yang biasa dipakai dalam ilmu komunikasi. Bagi penulis, hal ini tidaklah tabu karena dakwah itu sendiri sangat erat kaitannya dengan komunikasi, bahkan boleh dikatakan sangat mirip yaitu keduanya memiliki pengertian suatu kegiatan penyampaian

\footnotetext{
* Dosen Fakultas Dakwah \& Komunikasi UIN Alauddin Makassar
} 
pesan yang berimbas pada perubahan terhadap diri seseorang. Meminjam istilah Schramm, bahkan keduanya pun memenuhi syarat-syarat tertentu yang terdiri dari 3 unsur yaitu, sumber (source), isi pesan (message), dan tujuan (destination) ${ }^{1}$, yakni masing-masing keduanya memiliki gaya memikat.

Jurnalisme Dakwah merupakan institusi yang berkiprah dalam kegiatan dakwah dengan menggunakan metode jurnalistik dalam pencapaian tujuannya. ${ }^{2}$ Proses kerjanya adalah meliput, mengolah, dan menyebarluaskan berbagai peristiwa dengan muatan nilai-nilai Islam dengan mematuhi kaidah-kaidah jurnalistik dan norma-norma yang bersumber dari AlQur'an dan Sunnah Rasulullah SAW.

Jurnalistik dakwah (Islam) bisa dikatakan sebagai crusade journalism, yaitu jurnalistik yang memperjuangkan nilai-nilai tertentu, yakni nilai-nilai Islam. Jurnalistik dakwah juga sebagai pembimbing rohani \& mengemban misi 'amar ma'ruf nahyi munkar (Q.S. 3:104). ${ }^{3}$ Eksistensinya sebagai satu kekuatan untuk mendesain dakwah bercorak berita yang mampu memberikan spirit pencerahan kepada khalayak. Jurnalistik dakwah menawarkan the idea is the message, yaitu bagaimana nila-nilai agama dapat dituangkan dalam bentuk pesan yang kompetitif di antara idea-idea lainnya yang juga ditawarkan kepada sasaran yang sama. ${ }^{4}$

Jurnalisme dakwah pun merupakan jurnalis yang bergerak dibidang informasi dan teknologi dalam kegiataan penerbitan tulisan yang mengabdikan diri kepada nilai agama Islam. Tekanannya tentu pada media pers, baik surat kabar, majalah maupun tabloid. Karena melalui media pers, pesan dakwah itu tentu saja disampaikan melalui karya tulisan di media pers. Karya tulisan di media pers itu bisa berbentuk berita, feature, laporan, tajuk rencana, artikel, dan karya jurnalistik lainnya. ${ }^{5}$

\footnotetext{
${ }^{1}$ Wilbur Schramm, seorang ahli komunikasi kenamaan, dalam karyanya Communication Research In The United States. Schramm mengatakan "Komunikasi akan berhasil apabila pesan yang disampaikan oleh komunikator cocok dengan kerangka acuan (frame of reference), yakni panduan pengalaman dan pengertian (collection of expreiences and meanings) yang pernah diperoleh komunikan." Wilbur Schramm \& Roberts Donald f., The Process and Effects of Mass Communication, revised edition, (Urbana-Chicago-London: University of Illionis Press, 1971).

${ }^{2}$ Kustadi Suhandang, Manajemen Pers Dakwah; Dari Perencanaan hingga Pengawasan. Cet. I; (Bandung:

MARJA, 2007), h. 19.

${ }^{3}$ Suf Kasman, Jurnalisme Universal; Menelusuri Prinsip-Prinsip Dakwah bi al-Qalam dalam Al-Qur'an. Cet. I; (Jakarta: Teraju, 2004), h. 6.

${ }^{4}$ Toto Tasmara, Komunikasi Dakwah. Cet. II; (Jakarta: Gaya Media Pratama, 1997), h. xviii.

${ }^{5}$ Sudirman Tebba, Jurnalistim Baru (Ciputat: Kalam Indonesia. 2005) h. 9.
} 


\section{Pembahasan}

Selama ini tidak seorangpun menyangkal bahwa mesjid merupakan pusat dakwah yang efektif. Akan tetapi dengan perkembangan dan kemajuan teknologi yang pesat dari tahun ke tahun, kini dakwah tak cukup hanya dipusatkan di masjid saja tanpa mencoba mencari alternatif lain mengembangkannya di luar masjid dengan menggunakan sarana serta prasarana yang tersedia. Hal itu dilakukan agar relevan dengan kebutuhan masyarakat modern, yang juga semakin beraneka ragam, serta meluasnya diferensiasi sosial. ${ }^{6}$

Di tengah-tengah perkembangan dan pembangunan sektor komunikasi yang menggembirakan sekarang ini, ajakan atau pemikiran untuk mengembangkan dakwah dengan mengerling ke pers tentu saja merupakan langkah yang tepat dan bijak. Terlebih bila dikaitkan dengan peranan, fungsi dan kerja pers sebagai agen pembaharuan untuk memublikasikan suatu pesan atau informasi yang maksimun untuk menciptakan pengetahuan dan pemahaman bagi khalayak yang dilakukan oleh organisasi atau perusahaan. ${ }^{7}$

Sekarang sudah saatnya para pemikir, pakar, muballigh, ulama dan pemuka Islam lainnya memanfaatkan serta menggunakan peluang maupun pengaruh yang dimiliki pers-dalam hal ini jurnalistik untuk berdakwah—guna meningkatkan dakwah demi syiar Islam.

Eksistensi jurnalistik Dakwah, suatu ketika bisa menjadi sumbuh peletup gerakan sosial, dan pada waktu yang lain ia bisa menjadi magnet penenang massa. Jurnalistik Dakwah bisa menjadi katup stabilitas sosial, dan bisa juga menjadikan bagian penting dari proses transformasi sosial. Semua ini bergantung pada sistem sosial yang melingkupinya. ${ }^{8}$

Mungkin tidak terlalu keliru jika dikatakan jurnalistik dakwah adalah salah satu tulang punggung dalam Islam. Islam tidak hanya sebagai keyakinan yang mau disiarkan, tetapi juga petunjuk dan jalan hidup (way of life). Jurnalistik dakwah itu bagian yang tidak terpisahkan dari gerak langkah, pola pikir dan nasehat-nasehat ajaran Islam. ${ }^{9}$ Secara faktual, jurnalistik dakwah senyawa kehidupan yang mengalir dari hulu sampai ke hilir. Ini merupakan sejarah khas yang dimiliki Islam. ${ }^{10}$

\footnotetext{
${ }^{6}$ A. Muis, Op. Cit., h. 133.

${ }^{7}$ Suf Kasman, Pers dan Pencitraan Umat Islam di Indonesia; analisis Isi Pemberitaan Kompas dan Republika. Cet. I; (Jakarta: Badan Litbang dan Diklat Kementerian Agama RI, 2010), h. 54.

${ }^{8}$ Kurdi Mustofa, Dakwah Di Balik Kekuasan. Cet. I; (Bandung: PT Remaja Rosdakarya, 2012), h. iii.

${ }^{9}$ Ibid., h. 43.

${ }^{10}$ Ibid., h. 61-62.
} 


\section{Wartawan Muslim, Pelanjut Risalah Nabi}

Posisi wartawan Muslim sebagai pelanjut risalah Nabi dipandang sebagai sebuah kajian yang penting di era informasi saat ini. Hal itu didasari sebuah pandangan bahwa wartawan Muslim adalah salah seorang guru masyarakat informasi. Apa yang lahir dari tangan mereka kemudian menjadi pelajaran yang diserap oleh masyarakat melalui media massa. Oleh karena posisinya yang sangat penting dalam masyarakat, maka wartawan Muslim bisa menjadi penyebar kebajikan di tengah masyarakat melalui media massanya. Itu dengan catatan apabila dia bekerja secara ideal sesuai dengan norma yang berlaku dalam profesinya. Pada perpektif kajian dalam makalah ini wartawan disetarakan posisinya dengan para da' ${ }^{1} .{ }^{11}$

Dalam konteks pendidikan jurnalisme, wartawan Muslim dilihat sebagai sosok juru dakwah ( $\left.d a^{\prime} i\right)$ di bidang pers, yakni mengemban $d a^{\prime}$ wah bi al-qalam. Ia menjadi khalifah (wakil) Allah di dunia media massa dengan memperjuangkan tegaknya nilai-nilai, norma, etika, dan syariat Islam. Ia memiliki tanggung jawab profetik Islam; mengupayakan agar ajaran Islam tetap dan selalu fungsional serta aktual dalam kehidupan. Jurnalis Muslim tidak boleh tinggal diam begitu saja jika melihat ada kemunkaran dalam dunia yang digelutinya, misalnya menyaksikan pencitraan negatif tentang Islam atau ada rekayasa yang memojokkan Islam dan umatnya di media massa, maka jurnalis Muslim seketika itu langsung membela dan meluruskan sesuai dengan fakta sebenarnya. Ia sangat kritis terhadap lingkungan luar dan sanggup menyaring informasi Barat yang kadang menanam bias kejahatan terhadap Islam. $^{12}$

Sebagai wartawan Muslim, tanggung jawab moral yang diambilnya sangatlah besar. Setiap langkah, setiap tulisan yang akan diluncurkan mempunyai misi amar ma'ruf nahi munkar, dalam pengertian yang seluas-luasnya. Inilah yang membedakan antara wartawan sekuler yang menganut asas bebas nilai dengan wartawan Muslim yang berasas tidak bebas nilai. Adapun nilai-nilai yang diperjuangkan adalah nilai-nilai Islami yang bermuara pada keselamatan, keamanan dan kesejahteraan alam serta seisinya.

Penyematan lain dari wartawan Muslim adalah penyuara kebenaran. Mereka adalah manusia bermoral tinggi, dan tahan sogok. Dengan demikian motivasi bekerja seorang wartawan bukanlah karena imbalan semata. Dibayar atau tidak kalau itu merupakan

${ }^{11}$ Jurnal Dakwah Tabligh, Vol. 15, No.2, Desember 2014, h. 150-151.

${ }^{12}$ Suf Kasman, Jurnalisme Universal; Op. Cit., h. 7. 
panggilan hati nurani, ia akan melakukannya. Panggilan profesionalisme itulah yang membedakan antara wartawan tukang yang menulis sesuai dengan keinginan sumber berita atau keinginan perusahaan dengan wartawan profesional yang tetap komitmen atas idealisme. Wartawan yang terakhir inilah mampu menggurat pena dengan mesiu kesadaran diri yang memantik kesadaran publik. ${ }^{13}$

Para wartawan Muslim yang disebut juga sebagai penyambung lidah ajaran Islam dituntut untuk memiliki sifat-sifat kenabian yakni shidiq, amanah, tabligh, fathonah. Setidaknya ada lima peran media dakwah, yaitu sebagai Pendidik (Muaddib), yaitu melaksanakan fungsi edukasi yang Islami Sebagai Pelurus Informasi (Musaddid). Setidaknya ada tiga hal yang harus diluruskan oleh para jurnalis Muslim. Pertama, informasi tentang ajaran dan umat Islam. Kedua, informasi tentang karya-karya atau prestasi umat Islam. Ketiga, lebih dari itu jurnalis Muslim dituntut mampu menggali -melakukan investigative reporting - tentang kondisi umat Islam di berbagai penjuru dunia Sebagai Pembaharu (Mujaddid), yakni penyebar paham pembaharuan akan pemahaman dan pengamalan ajaran Islam (reformisme Islam) Sebagai Pemersatu (Muwahid), yaitu harus mampu menjadi jembatan yang mempersatukan umat Islam Sebagai Pejuang (Mujahid), yaitu pejuangpembela Islam. ${ }^{14}$

\section{Landasan Jurnalistik Dakwah}

"Dasar hukum" Jurnalistik Dakwah yaitu ayat Al-Quran yang juga menjadi dasar aktivitas dakwah secara umum:

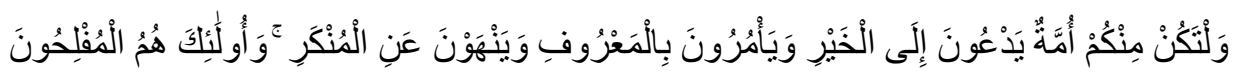

"Dan hendaklah ada di antara kamu segolongan umat yang menyeru kepada kebaikan, menyuruh kepada yang ma'ruf, dan mencegah dari yang munkar. Merekalah orangorang yang beruntung." (QS Ali Imran:104).

Menyeru kepada kebaikan (al-khair) dan 'amar ma'ruf nahyi munkar, berdasarkan ayat tersebut, menjadi visi-misi jurnalistik dakwah. Informasi, pesan, tulisan, atau berita yang disebarkan dalam konteks jurnalistik dakwah senantiasa mengacu pada kebaikan dalam perspektif Islam dan bertujuan menegakkan kebenaran serta mencegah hal-hal munkar

${ }^{13}$ Ade Ma'ruf (pen.), Menulis Itu Indah; Pengalaman Para Penulis Dunia. Cet. II; (Yogyakarta: Jendela, 2003), h.

${ }^{14}$ Suf Kasman, Jurnalisme Universal; Op. Cit., h. 8. 
(bertentangan dengan syariat Islam), ${ }^{15}$ bukan menyampaikan sajian yang sifatnya gemar membuka issu baru yang sensetif di masyarakat. ${ }^{16}$ Melainkan fakta dan opini objektif dan berimbang. ${ }^{17}$

Dalam sebuah penggalan hadis Nabi Muhammad Saw riwayat Al Bukhari dinyatakan

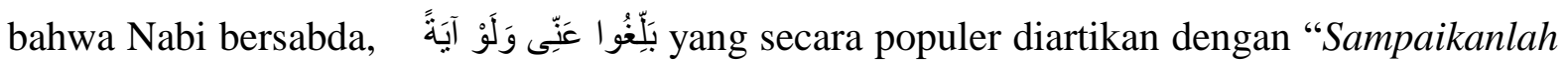

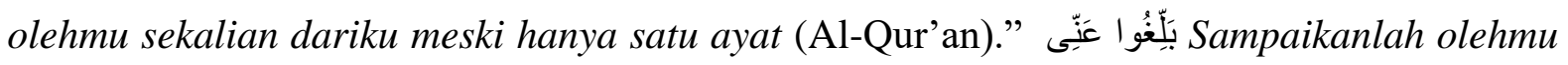
sekalian dariku meski Anda menggunakan media massa. Hal ini berarti mengajak untuk mempertinggi kualitas 'amar ma'ruf nahyi munkar merupakan pekerjaan Nabi Muhammad Saw selama hidupnya. Perilaku seperti ini tetap menjadi bentuk alternatif dari jurnalistik dakwah yang pernah Rasulullah Saw lakukan saat membangun komunikasi dengan para pemimpin suku dan pemimpin negara lain. Beliau mengirim utusan yang membawa surat ajakan masuk Islam.

\section{Jurnalistik Rintisan Nabi Muhammad Saw}

Pada masa awal setelah diangkat sebagai utusan Allah, Nabi Muhammad Saw membangun komunikasi dengan para pemimpin suku dan pemimpin negara lain. Beliau mengirim utusan yang membawa surat ajakan masuk Islam. Korespondensi melalui surat itu tujukan kepada Heraclius, Kisra, Muqauqis di Mesir, Harits Al-Ghassani (Raja Hira), Hercules di Bizantium, Harits Al-Himyari (Raja Yaman) dan kepada Najasi, penguasa Abesinia (Ethiopia).

Surat Rasulullah itu antara lain berbunyi, "Saya mengajak tuan memperkenankan panggilan Allah, peluklah Islam supaya tuan selamat". Surat-surat tersebut selalu diakhiri sebuah stempel dari perak yang dicetak dengan tiga baris tulisan: Baris pertama: Allah; baris kedua: Rasul; dan baris ketiga: Muhammad. Lalu Beliau memilih beberapa orang sahabat yang berpengalaman sebagai kurir untuk menemui raja-raja tersebut. Sepanjang hidupnya, Rasulullah Saw 'menulis risalah-nya sebanyak 43 buah surat. ${ }^{18}$

\footnotetext{
15 Asep Syamsul M. Romli, Jurnalistik Dakwah: Visi dan Misi Dakwah Bil Qalam, (Bandung: PT Remaja Rosdakarya, 2003), h. 3.

${ }^{16}$ Samsul Wahidin, Filter Komunikasi Media Elektronika. Cet. I; (Yogyakarta: Pustaka Pelajar, 2006), h. 5.

${ }^{17}$ Ibid., h. 92.

${ }^{18}$ http://www.infoyunik.com/2015/03/surat-surat-ini-saksi-dakwah-rasulullah.html
} 
Berdakwah memang memiliki banyak cara. Secara garis besar ada dua jenis dakwah; ada yang disebut dengan dakwah cultural, meliputi lewat sosial, medsos, dan budaya. Lalu ada dakwah struktural; yakni berdakwah lewat jalur kekuasaan dan birokrasi. ${ }^{19}$

Seiring dengan perkembangan zaman, kini metode berdakwah tidak lagi hanya dalam diskusi atau membuka forum tertentu saja. Tetapi, dakwah juga dilakukan dengan cara yang lebih modern dalam artian tidak hanya melalui percakapan dalam forum diskusi melainkan memanfaatkan adanya teknologi melalui media massa khususnya media jurnalistik, seperti buku-buku, majalah, surat kabar, buletin, risalah, kuliah-kuliah tertulis, pamflet, pengumuman tertulis, spanduk dan lain-lain yang mengandung pesan dakwah sangat penting dan efektif.

Keuntungan lain dari dakwah model ini tidak menjadi musnah meskipun sang dai, atau penulisnya sudah wafat. Menyangkut dakwah bi al-qalam ini Ali bin Abi Thalib mengungkap sebuah pameo klasik, "Tulisan adalah tamannya para ulama”. Rasulullah Saw bersabda, "Sesungguhnya tinta para ulama adalah lebih baik dari darahnya para syuhada". 20

Secara langsung memang tidak ditemui dalam Al-Quran anjuran menggunakan media tulisan sebagai alat dakwah, tetapi secara tersirat dapat dipahami dari satu surat yang terdapat dalam Al-Quran, yaitu surat Al-Qalam. Dalam surat tersebut dinyatakan bahwa Allah SWT bersumpah dengan huruf nun, sebagai isyarat terpenting tentang peran huruf, pena dan tulisan dalam pelaksanaan dakwah Islamiyah. Hal ini dapat lebih dipahami dengan menelaah surat Al-Qalam ayat 1.

$$
\text { نَوَالْقَلَمِ وَمَا يَسْطُرُونَ }
$$

\section{Nun, demi kalam dan apa yang mereka tulis}

Ini menunjukkan bahwa Rasulullah Saw selain melaksanakan metode lisan juga dengan jurnalistik dakwah melalui tulisan (surat).

${ }^{19}$ Kurdi Mustofa, Op. Cit., h. 64.

${ }^{20}$ Suf Kasman, Jurnalisme Universal; Op. Cit., h. 3. 


\section{Manajemen Pers Dakwah}

Setiap organisasi atau lembaga tertentu dapat dipastikan memiliki satu atau beberapa tujuan yang menunjukan arah dan menyatukan gerak sarana yang terdapat dalam lembaga tersebut. $^{21}$

Pada perkembangan selanjutnya manajemen ternyata sangat diperlukan dan bermanfaat bagi setiap usaha dalam pelbagai lapangan, apalagi di zaman modern sekarang ini boleh dikatakan bahwa tidak ada suatu usaha yang bisa sukses tanpa menerapkan manajemen. Maka usaha dakwah yang jangkauannya sangat luas dan kompleks dibandingkan dengan usaha atau kegiatan bisnis, tentulah tidak dapat berjalan secara efektif dan efisien apabila tidak dengan memanfaatkan manajemen. Oleh karena itu, apabila dakwah sebagai sarana penyiaran ajaran Islam di tengah-tengah kehidupan manusia, maka dalam pelaksanaannya tidak bisa hanya dengan mengandalkan secara orang perseorangan tetapi hendaknya dilakukan melalui kerjasama dalam organisasi modern dengan mengikuti prinsip-prinsip manajemen yang baik agar lebih mudah tercapai sesuai dengan hasil yang diharapkan ${ }^{22}$

Prinsip-prinsip Manajemen Pers Dakwah yang biasa disebut 'amaliyyah al-iddâriyyah tersebut merupakan sebuah kesatuan yang utuh yang terdiri dari; takhthîth (perencanaan strategi), thanzhîm (pengorganisasian), tawjîh (penggerakan), riqâbah (pengawasan atau evaluasi). ${ }^{23}$ Adapun penjabarannya dapat disimak berikut ini:

Pertama, Takhthîth (perencanaan strategi).

Takhthîth (perencanaan strategi) dakwah adalah proses perencanaan tugas, mengelompokkan tugas, menghimpun dan menempatkan tenaga-tenaga pelaksana dalam kelompok-kelompok tugas dan kemudian menggerakkan ke arah pencapaian tujuan jurnalistik dakwah.

\footnotetext{
${ }^{21}$ Kreitner, salah seorang pakar Management, mengatakan; “Tujuan yang akan dicapainya adalah keadaan masa yang akan datang yang lebih baik ketimbang keadaan sebelumnya. Adapun proses pencapaain tujuannya itu memerlukan suatu proses manajemen yang sehat dalam arti terarah. Efektif dan efesien tepat sasaran. Terarah di sini dimaksud dengan aktivitas yang telah di lakukan terpusat pada tercapainya tujuan yang telah di tentukan, yaitu melakukan kegiatan-kegiatan rasional yang tepat guna untuk menghasilkan hasil akhir yang telah diterapkan sebelumnya. Sedangkan efektif dan efesien dimaksudkan adanya penggunaan sarana yang terbatas pada hal-hal yang diperlukan. Karena itu pula organisasi atau lembaga suatu manajemen diartikan sebagai wadah sarana manajemen yang diperlukan dan sebagai alat pencapaian tujuan". Robert Kreitner, Management. (Boston: Hougton Mifflin Company, $4^{\text {th }}$ Edition, 1989), h. 9.

${ }^{22}$ Mahmuddin, Manajemen Dakwah Dasar: Proses, Model, Pelatihan dan Penerapannya. Cet. I; (Samata-Gowa: Alauddin University Press, 2011), h. 18.

${ }^{23}$ Akrim Ridha, Menjadi Pribadi Sukses; Panduan Melejitkan Potensi Diri. (Bandung: Syamil Cipta Media, 2002), h. 60. Lih. Juga M. Munir \& Wahyu Ilaihi, Manajemen Dakwah. Cet. II; (Jakarta: Kencana Prenada Media Group, 2006), h. xiv dan 93.
} 
Takhthith (perencanaan strategi), merupakan perpaduan dari perencanaan (planning) dan management dakwah untuk mencapai suatu tujuan. Di dalam mencapai tujuan tersebut strategi dakwah harus dapat menunjukkan bagaimana operasionalnya secara tekhnik (taktik) harus dilakukan, dalam arti kata bahwa pendekatan (approach) bisa berbeda sewaktu-waktu bergantung pada situasi dan kondisi. Untuk mantapnya strategi dakwah, maka segala sesuatunya harus dipertautkan dengan komponen-komponen yang merupakan jawaban terhadap pertanyaan dalam rumus Lasswell, yaitu:

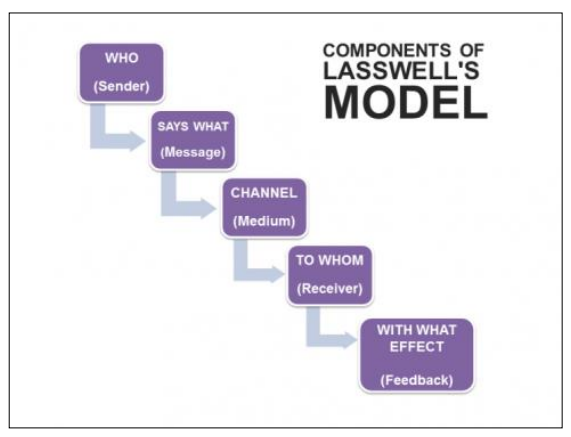

- Who? (Siapa da'i atau penyampai pesan dakwahnya?)

- Says What? (Pesan apa yang disampaikan?)

- In Which Channel? (Media apa yang digunakan?)

- To Whom? (Siapa Mad'unya atau pendengarnya?)

- With what Effect? (Efek apa yang diharapkan?). ${ }^{24}$

\section{Kedua, Thanzhîm (pengorganisasian)}

Istilah thanzhim (pengorganisasian) mempunyai dua pengertian. Pertama organisasi diartikan sebagai lembaga atau kelompok fungsional, misalnya sebuah perusahaan atau sebuah perkumpulan. Kedua merujuk pada proses pengorganisasian yaitu bagaimana pekerjaan diatur dan dialokasikan diantara para anggota, sehingga tujuan organisasi itu dapat tercapai secara efektif dengan batas-batas yang pasti. ${ }^{25}$ Substansi ini merupakan tahap yang dimana segala anggota penyelenggara acara berkumpul bersama dan saling bekerja sama dengan harapan tujuan jurnalistik dakwah tersebut bisa sukses. Meminjam istilah Mahmuddin, "Yang penting memiliki kejelasan aktifitas, tujuan \& misi". ${ }^{26}$

\footnotetext{
${ }^{24}$ Tata Sukayat, Quantum Dakwah. Cet. I; (Jakarta: PT Rineka Cipta, 2009), h. 16.

${ }^{25}$ R. Wayne Pace \& Don F. Faules yang dialihbahasakan oleh Deddy Mulyana dengan judul Komunikasi Organisasi; Strategi Meningkatkan Kinerja Perusahaan. Cet. VI; (Bandung: PT Remaja Rosdakarya, 2006), h. 11. ${ }^{26}$ Mahmuddin, Op. Cit., h. 18.
} 
Dengan demikian maka tujuan organisasi dakwah adalah kegiatan dan upaya bersama untuk mengaktualisasikan nilai-nilai dalam ajaran Islam dalam bentuk amar makruf nahi munkar dan 'amal sholeh dalam kehidupan sehari-hari, baik secara pribadi, keluarga dan masyarakat, sehingga mewujudkan ummat yang baik, sejahtera lahir batin dan bahagia dunia akhirat. Tujuan organisasi dakwah sebagaimana dirumuskan di atas merupakan tujuan primer atau tujuan akhir.

Adapun tujuan sekunder (tujuan perantara) dapat dirumuskan secara lebih teknis, operasional dan terukur, di samping juga harus disesuaikan dengan bidang dan permasalahannya.

\section{Ketiga, Tawjîh (penggerakan)}

Tawjîh (Penggerakan dakwah) adalah suatu proses pemberian motivasi, pengarahan dan bimbingan oleh para pelaksana dakwah, penggerakan komunikasi dan organisasi serta penerapan dan pengembangan kepemimpinan dakwah. Esensi Tawjîh (Penggerakan dakwah) di sini adalah untuk membentuk pendapat umum yang sehat, atau public opini. Dengan selalu adanya penggerakan dakwah, maka terdapatlah masyarakat yang sehat. ${ }^{27}$

Langkah-langkah Penggerakan Dakwah mempunyai beberapa karakteristik, meliputi:

a) Saling mengingatkan menjadi bagian yang tak terpisahkan dari kehidupan keseharian umat

b) Peduli dan saling memberdayakan (jasad \& bunyân)

c) Mempunyai sikap bijaksana, tidak keras kepala, pemaaf, mempunyai dan mengembangkan tradisi syûra dalam menyelesaikan berbagai masalah dan melibatkan Allah akan memberikan yang terbaik.

d) Berjiwa 'izzah (percaya diri) terhadap siapa pun, termasuk yang tidak seakidah.

e) Berpaham keagamaan moderat dan dapat memberikan keteladanan. ${ }^{28}$ Jadi, penggerakan dakwah itu bisa disebut dengan nama lain

- Pemberian motivasi (Motivating) ${ }^{29}$

- Pembimbingan (Directing)

\footnotetext{
${ }^{27}$ Fathul Bahri An-Nabiry, Meniti Jalan Dakwah; Bekal Perjuangan Para Da'i. Cet. I; (Jakarta: Amzah, 2008), h. 43.

${ }^{28}$ Muhammad Alwi Uddin, Problematika Gerakan Dakwah Muhammadiyah di Sulawesi-Selatan. Cet. I; (SamataGowa: Alauddin University Press, 2013), h. 108.

${ }^{29}$ Khatib Pahlawan Kayo, Manajemen Dakwah: Dari Dakwah Konfensional Menuju Dakwah Professional. (Jakarta: Amzah, 2007), h. 66.
} 
- Menjalin hubungan (Coordinating)

- Penyelenggaraan komunikasi (Communicating)

Keempat, Riqâbah (pengawasan atau evaluasi).

Riqâbah (pengawasan atau evaluasi) merupakan suatu proses pengumpulan data menganalisis informasi tentang efektifitas dan dampak dari suatu tahap atau keseluruhan program. Ada juga yang mengemukakan bahwa evaluasi dakwah adalah meningkatkan pengertian manajerial dakwah dalam sebuah program formal yang mendorong para menejer atau pemimpin dakwah untuk mengamati perilaku anggotanya, lewat pengamatan yang lebih mendalam yang tidak dapat dihasilkan melalui saling pengertian diantara kedua belah pihak. $^{30}$

Adapun prosedur riqâbah (pengawasan atau evaluasi) dakwah, yaitu :

1. Menetapkan standar atau tolak ukur

2. Rencana evaluasi

3. Mengumpulkan data

4. Menganalisis data

5. Menyajikan hasil analisis

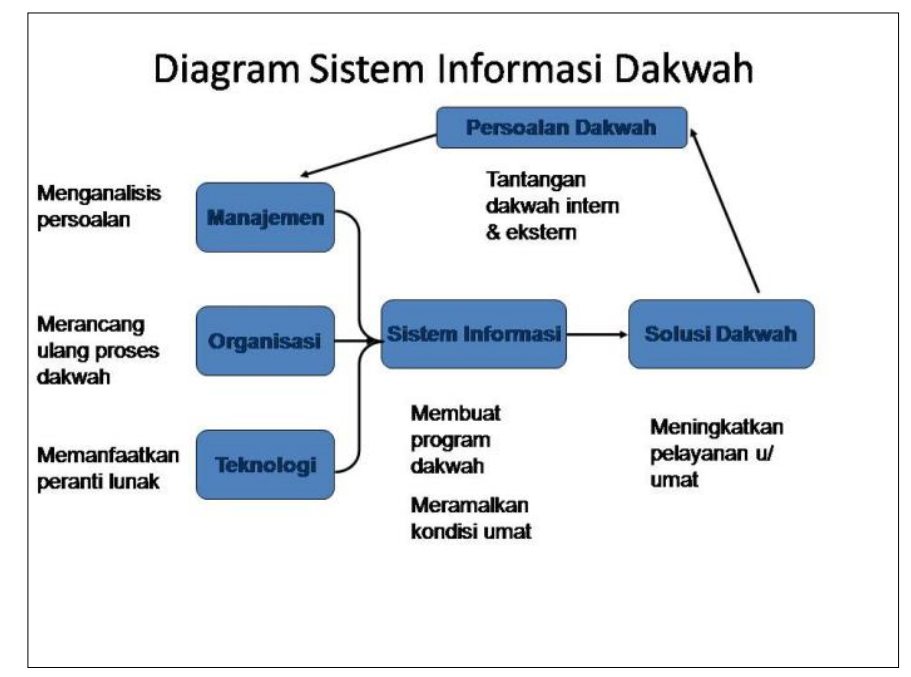

\section{Jurnalistik Dakwah, Sebuah Model Komunikasi Islami}

Jurnalistik Dakwah adalah jurnalistik dakwah yang unsur-unsurnya disesuaikan model komunikasi Islami. Tujuan Jurnalistik dengan model komunikasi pada umumnya yaitu

\footnotetext{
${ }^{30} \mathrm{http}: / /$ tari-dakwah.blogspot.co.id/2010/06/evaluasi-dakwah.html
} 
mengharapkan partisipasi dari komunikan atas ide-ide atau pesan-pesan yang disampikan oleh pihak komunikator (wartawan) sehingga pesan-pesan yang disampaikan tersebut terjadilah perubahan sikap dan tingkah laku yang diharapkan, sedangkan tujuan Jurnalistik Dakwah yaitu mengharapkan terjadinya perubahan atau pembentukan sikap atau tingkah laku sesuai dengan ajaran agama Islam.

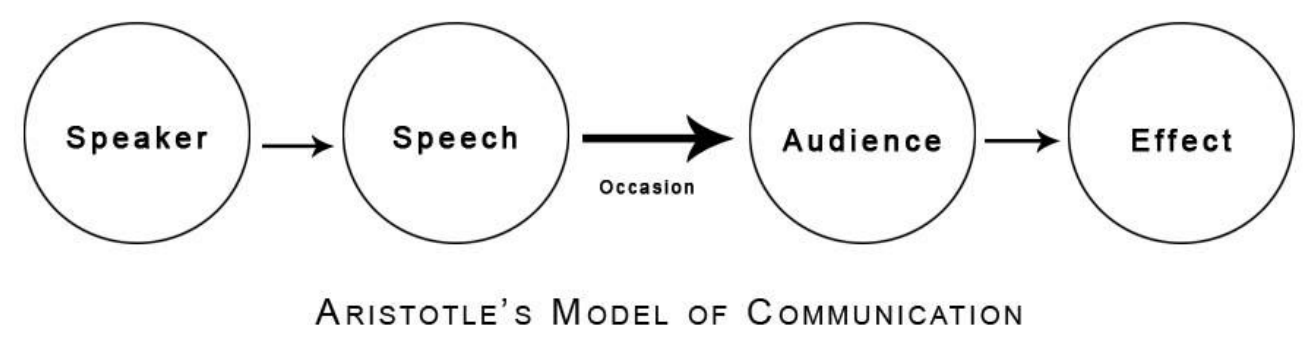

Jurnalistik dakwah dengan model komunikasi bisa disebut satu kesatuan. Ilmu komunikasi adalah landasan teori umum dalam jurnalistik. Dapat dipahami bahwa jurnalistik dakwah merupakan aktivitas mencari, mengolah dan menyampaikan informasi kepada masyarakat dalam bentuk tulisan dan gambar dengan menggunakan media massa yang mengedepankan syiar Islam dan mengutamakan amar-makruf nahi-munkar.

Hubungan ilmu komunikasi Islami dengan jurnalistik dakwah dapat disimpulkan, dalam komunikasi itu ada yang menggunakan media massa sebagai wadah penyampaian pesannya (disebut dengan komunikasi massa) dan untuk memproduksi pesan yang akan disampaikan kepada khalayak tersebut memerlukan cara atau aktivitas jurnalistik. Komunikasi massa adalah komunikasi melalui media massa dan untuk memproduksi media massa memerlukan aktivitas jurnalistik.

Proses penyampaian pesan dakwah berkaitan erat dengan proses komunikasi. Agama Islam sangat memperhatikan pentingnya mengomunikasikan dakwah. ${ }^{31}$ Kendati komunikasi dakwah itu dibatasi oleh tanggungjawab religius. ${ }^{32}$

Seiring dengan perkembangan media dakwah sebagai sarana komunikasi islami selama ini, telah mendudukkan media tulis ini sebagai alat untuk membentuk opini masyarakat. Dengan media dakwah pikiran orang (pembaca) dapat dikendalikan, sehingga barang siapa

${ }^{31}$ Atwar Bajari \& S. Sahala Tua Saragih (peny.), Komunikasi Kontekstual; Teori \& Praktik Komunikasi Kontemporer. Cet. I; (Bandung: PT Remaja Rosdakarya, 2011), h. 33-34.

${ }^{32}$ A. Muis, Komunikasi Islami. Cet. I; (Bandung: PT Remaja Rosdakarya, 2001), h. 33-34 
yang dapat menguasai media biasanya akan lebih besar peluangnya untuk dapat menguasai massa. Dan untuk dapat menguasai media ada bayak persyaratan yang harus dipenuhi, sehingga seseorang dapat digolongkan sebagai pembentuk opini. Diantaranya seseorang dituntut memiliki ketrampilan menulis yang memadai. Semakin tinggi kemampuan menulis semakin besar peluang untuk mendapatkan pembaca. Karena ditengah-tengah persaingan kehidupan selama ini orang sudah mulai selektif dalam memilih tulisan yang berkualitas.

\section{Kesimpulan}

Menulis dalam Islam merupakan suatu kewajiban setelah perintah untuk membaca (belajar, meneliti dan menelaah). Menulis berarti menyimpan apa yang telah dibaca dalam sebuah media yang bisa diakses oleh siapa saja. Dalam perkembangannya, menulis memiliki peran yang sangat urgen dalam sejarah kejayaan umat Islam beberapa abad silam.

Mayoritas ulama terdahulu yang menjadi arsitek kejayaan Islam masa lalu adalah para penulis ulung yang telah menghasilkan berbagai buah karya mereka yang sampai saat ini masih menjadi rujukan umat Islam sedunia dalam berbagai disiplin keilmuan. Bahkan, Eropa yang kemajuannya hari ini telah jauh meninggalkan dunia Islam ternyata pernah mengekor pada kemajuan umat Islam masa silam. Dan berbagai kemunduran umat Islam dewasa ini bisa dipastikan karena tradisi membaca dan menulis yang pernah dipopulerkan oleh para ulama masa lalu telah ditinggalkan.

\section{DAFTAR PUSTAKA}

An-Nabiry, Fathul Bahri. Meniti Jalan Dakwah; Bekal Perjuangan Para Da ’i. Cet. I; (Jakarta: Amzah, 2008).

Bajari, Atwar \& S. Sahala Tua Saragih (peny.). Komunikasi Kontekstual; Teori \& Praktik Komunikasi Kontemporer. Cet. I; (Bandung: PT Remaja Rosdakarya, 2011).

Bajari, Atwar \& S. Sahala Tua Saragih (peny.). Komunikasi Kontekstual; Teori \& Praktik Komunikasi Kontemporer. Cet. I; (Bandung: PT Remaja Rosdakarya, 2011).

Kasman, Suf. Jurnalisme Universal; Menelusuri Prinsip-Prinsip Dakwah bi al-Qalam dalam Al-Qur'an. Cet. I; (Jakarta: Teraju, 2004).

. Pers dan Pencitraan Umat Islam di Indonesia; analisis Isi Pemberitaan Kompas dan Republika. Cet. I; (Jakarta: Badan Litbang dan Diklat Kementerian Agama RI, 2010).

Kayo, Khatib Pahlawan. Manajemen Dakwah: Dari Dakwah Konfensional Menuju Dakwah Professional. (Jakarta: Amzah, 2007).

Kreitner, Robert. Management. (Boston: Hougton Mifflin Company, $4^{\text {th }}$ Edition, 1989).

M. Romli, Asep Syamsul. Jurnalistik Dakwah: Visi dan Misi Dakwah Bil Qalam, (Bandung: PT Remaja Rosdakarya, 2003). 
Ma'ruf (pen.), Ade. Menulis Itu Indah; Pengalaman Para Penulis Dunia. Cet. II; (Yogyakarta: Jendela, 2003).

Mahmuddin, Manajemen Dakwah Dasar: Proses, Model, Pelatihan dan Penerapannya. Cet. I; (Samata-Gowa: Alauddin University Press, 2011).

Muis, A. Komunikasi Islami. Cet. I; (Bandung: PT Remaja Rosdakarya, 2001).

Munir, M. \& Wahyu Ilaihi, Manajemen Dakwah. Cet. II; (Jakarta: Kencana Prenada Media Group, 2006).

Mustofa, Kurdi. Dakwah Di Balik Kekuasan. Cet. I; (Bandung: PT Remaja Rosdakarya, 2012).

Pace, R. Wayne \& Don F. Faules yang dialihbahasakan oleh Deddy Mulyana dengan judul

Komunikasi Organisasi; Strategi Meningkatkan Kinerja Perusahaan. Cet. VI; (Bandung: PT Remaja Rosdakarya, 2006).

Ridha, Akrim. Menjadi Pribadi Sukses; Panduan Melejitkan Potensi Diri. (Bandung: Syamil Cipta Media, 2002), h. 60.

Schramm, Wilbur \& Roberts Donald f. The Process and Effects of Mass Communication, revised edition, (Urbana-Chicago-London: University of Illionis Press, 1971).

Suhandang, Kustadi. Manajemen Pers Dakwah; Dari Perencanaan hingga Pengawasan. Cet. I; (Bandung: MARJA, 2007).

Sukayat, Tata. Quantum Dakwah. Cet. I; (Jakarta: PT Rineka Cipta, 2009).

Tasmara, Toto. Komunikasi Dakwah. Cet. II; (Jakarta: Gaya Media Pratama, 1997).

Tebba, Sudirman. Jurnalistim Baru (Ciputat: Kalam Indonesia. 2005).

Uddin, Muhammad Alwi. Problematika Gerakan Dakwah Muhammadiyah di Sulawesi-Selatan. Cet. I; (Samata-Gowa: Alauddin University Press, 2013).

Wahidin, Samsul. Filter Komunikasi Media Elektronika. Cet. I; (Yogyakarta: Pustaka Pelajar, 2006).

\section{Jurnal \& Situs}

Jurnal Dakwah Tabligh, Vol. 15, No.2, Desember 2014.

http://tari-dakwah.blogspot.co.id/2010/06/evaluasi-dakwah.html

http://www.infoyunik.com/2015/03/surat-surat-ini-saksi-dakwah-rasulullah.html

http://kelasnyablogger.blogspot.co.id/2015/11/perngertian-dakwah-bil-qalam.html

\section{Endnote :}

1. Wilbur Schramm, seorang ahli komunikasi kenamaan, dalam karyanya Communication Research In The United States. Schramm mengatakan "Komunikasi akan berhasil apabila pesan yang disampaikan oleh komunikator cocok dengan kerangka acuan (frame of reference), yakni panduan pengalaman dan pengertian (collection of expreiences and meanings) yang pernah diperoleh komunikan." Wilbur Schramm \& Roberts Donald f., The Process and Effects of Mass Communication, revised edition, (Urbana-Chicago-London: University of Illionis Press, 1971).

2. Kustadi Suhandang, Manajemen Pers Dakwah; Dari Perencanaan hingga Pengawasan. Cet. I; (Bandung: MARJA, 2007), h. 19.

3. Suf Kasman, Jurnalisme Universal; Menelusuri Prinsip-Prinsip Dakwah bi al-Qalam dalam Al-Qur'an. Cet. I; (Jakarta: Teraju, 2004), h. 6.

4. Toto Tasmara, Komunikasi Dakwah. Cet. II; (Jakarta: Gaya Media Pratama, 1997), h. xviii.

5. Sudirman Tebba, Jurnalistim Baru (Ciputat: Kalam Indonesia. 2005) h. 9.

6. A. Muis, Op. Cit., h. 133.

7. Suf Kasman, Pers dan Pencitraan Umat Islam di Indonesia; analisis Isi Pemberitaan Kompas dan Republika. Cet. I; (Jakarta: Badan Litbang dan Diklat Kementerian Agama RI, 2010), h. 54.

8. Kurdi Mustofa, Dakwah Di Balik Kekuasan. Cet. I; (Bandung: PT Remaja Rosdakarya, 2012), h. iii.

9. Ibid., h. 43. 
10. Ibid., h. 61-62.

11. Jurnal Dakwah Tabligh, Vol. 15, No.2, Desember 2014, h. 150-151.

12. Suf Kasman, Jurnalisme Universal; Op. Cit., h. 7.

13. Ade Ma'ruf (pen.), Menulis Itu Indah; Pengalaman Para Penulis Dunia. Cet. II; (Yogyakarta: Jendela, 2003), h.

14. Suf Kasman, Jurnalisme Universal; Op. Cit., h. 8.

15. Asep Syamsul M. Romli, Jurnalistik Dakwah: Visi dan Misi Dakwah Bil Qalam, (Bandung: PT Remaja Rosdakarya, 2003), h. 3.

16. Samsul Wahidin, Filter Komunikasi Media Elektronika. Cet. I; (Yogyakarta: Pustaka Pelajar, 2006), h. 5.

17. Ibid., h. 92.

18. http://www.infoyunik.com/2015/03/surat-surat-ini-saksi-dakwah-rasulullah.html

19. Kurdi Mustofa, Op. Cit., h. 64.

20. Suf Kasman, Jurnalisme Universal; Op. Cit., h. 3.

21. Kreitner, salah seorang pakar Management, mengatakan; "Tujuan yang akan dicapainya adalah keadaan masa yang akan datang yang lebih baik ketimbang keadaan sebelumnya. Adapun proses pencapaain tujuannya itu memerlukan suatu proses manajemen yang sehat dalam arti terarah. Efektif dan efesien tepat sasaran. Terarah di sini dimaksud dengan aktivitas yang telah di lakukan terpusat pada tercapainya tujuan yang telah di tentukan, yaitu melakukan kegiatan-kegiatan rasional yang tepat guna untuk menghasilkan hasil akhir yang telah diterapkan sebelumnya. Sedangkan efektif dan efesien dimaksudkan adanya penggunaan sarana yang terbatas pada hal-hal yang diperlukan. Karena itu pula organisasi atau lembaga suatu manajemen diartikan sebagai wadah sarana manajemen yang diperlukan dan sebagai alat pencapaian tujuan". Robert Kreitner, Management. (Boston: Hougton Mifflin Company, $4^{\text {th }}$ Edition, 1989), h. 9.

22. Mahmuddin, Manajemen Dakwah Dasar: Proses, Model, Pelatihan dan Penerapannya. Cet. I; (Samata-Gowa: Alauddin University Press, 2011), h. 18.

23. Akrim Ridha, Menjadi Pribadi Sukses; Panduan Melejitkan Potensi Diri. (Bandung: Syamil Cipta Media, 2002), h. 60. Lih. Juga M. Munir \& Wahyu Ilaihi, Manajemen Dakwah. Cet. II; (Jakarta: Kencana Prenada Media Group, 2006), h. xiv dan 93.

24. Tata Sukayat, Quantum Dakwah. Cet. I; (Jakarta: PT Rineka Cipta, 2009), h. 16.

25. R. Wayne Pace \& Don F. Faules yang dialihbahasakan oleh Deddy Mulyana dengan judul Komunikasi Organisasi; Strategi Meningkatkan Kinerja Perusahaan. Cet. VI; (Bandung: PT Remaja Rosdakarya, 2006), h. 11.

26. Mahmuddin, Op. Cit., h. 18.

27. Fathul Bahri An-Nabiry, Meniti Jalan Dakwah; Bekal Perjuangan Para Da'i. Cet. I; (Jakarta: Amzah, 2008), h. 43.

28. Muhammad Alwi Uddin, Problematika Gerakan Dakwah Muhammadiyah di Sulawesi-Selatan. Cet. I; (Samata-Gowa: Alauddin University Press, 2013), h. 108.

29. Khatib Pahlawan Kayo, Manajemen Dakwah: Dari Dakwah Konfensional Menuju Dakwah Professional. (Jakarta: Amzah, 2007), h. 66.

30. http://tari-dakwah.blogspot.co.id/2010/06/evaluasi-dakwah.html

31. Atwar Bajari \& S. Sahala Tua Saragih (peny.), Komunikasi Kontekstual; Teori \& Praktik Komunikasi Kontemporer. Cet. I; (Bandung: PT Remaja Rosdakarya, 2011), h. 33-34.

32. A. Muis, Komunikasi Islami. Cet. I; (Bandung: PT Remaja Rosdakarya, 2001), h. 33-34

33. Atwar Bajari \& S. Sahala Tua Saragih (peny.), Komunikasi Kontekstual; Teori \& Praktik Komunikasi Kontemporer. Cet. I; (Bandung: PT Remaja Rosdakarya, 2011), h. 240.

34. A. Muis, Komunikasi Islami. Cet. I; (Bandung: PT Remaja Rosdakarya, 2001), h. 46.

35. http://kelasnyablogger.blogspot.co.id/2015/11/perngertian-dakwah-bil-qalam.html 